\title{
ERJ
}

Engineering Research Journal

Faculty of Engineering

Menoufia University

\section{Effect of Using Plastic Waste on Mechanical Properties of Concrete}

\author{
Dr. Haider K. Ammash ${ }^{1}$, Dr. Sadjad A. Hemzah ${ }^{2}$ and Rasha Jasim ${ }^{3}$ \\ 1 Assist. Prof. Department of Civil Engineering, University of Al-Qadisiyah, Iraq. \\ e-mail: haider.ammash@qu.edu.iq \\ 2 Lecture Department of Civil Engineering, University of Al-Qadisiyah, Iraq. \\ e-mail: sadjad.amir@qu.edu.iq \\ 3 Assist. Lecture Department of Civil Engineering, University of Al-Qadisiyah, Iraq. \\ e-mail:Rasha.jasim@qu.edu.iq
}

\begin{abstract}
The present study deals with the effect of using plastic waste on mechanical properties of concrete. The experimental work consists of adding manually formed serrated plastic fibers by ratios of $(1 \%, 2 \%$ and $3 \%)$ of cement weight. Different lengths of fibers were used for each ratio with a constant width of $5 \mathrm{~mm}$. It was noticed from laboratory tests that the addition of plastic fibers improves the compressive strength, tensile strength and modulus of rupture of concrete, by different ratios, about $20 \%$, furthermore it could be a sufficient method to get rid of plastic waste.
\end{abstract}

Keywords: Recycle Plastic Waste, Mechanical Properties, Concrete, Compressive strength, Flexural Strength.

\section{INTRODUCTION}

Concrete is one of the most important materials used in construction, and because of its suitable cost and strength, an improvement of its mechanical and chemical properties was searched by many researchers by different processes, like adding different types polymers as a ratio of water content, or adding high strength steel fibers as a ratio of cement content. Some researches investigate the effect of adding low cost materials on the mechanical properties of concrete, and because plastic material is one of the environmental pollutants, it had been used in concrete mix in some researches.

Isamil and Al-Hashimi (2008) ${ }^{1}$ studied involved 86 experiments and 254 tests to determine the efficiency of reusing waste plastic in the production of concrete. Thirty kilograms of waste plastic of fabriform shapes was used as a partial replacement for sand by $0 \%, 10 \%, 15 \%$, and $20 \%$ with $800 \mathrm{~kg}$ of concrete mixtures. All of the concrete mixtures were tested at room temperature. These tests include performing slump, fresh density, dry density, compressive strength, flexural strength, and toughness indices. Seventy cubes were molded for compressive strength and dry density tests, and 54 prisms were cast for flexural strength and toughness indices tests. Curing ages of 3,7,14, and 28days for the concrete mixtures were applied in this work. The results proved the arrest of the propagation of microcracks by introducing waste plastic of fabriform shapes to concrete mixtures. This study insures that reusing waste plastic as a sand-substitution aggregate in concrete gives a good approach to reduce the cost of materials and solve some of the solid waste problems posed by plastics.

Rai, et. al.(2012) ${ }^{12}$ they worked om a number of concrete mixes where sand partially replaced by waste plastic flakes with varying percentages by volume of sand. Waste plastic mix concrete with and without superplasticizer. Forty-eight cube samples were moulded for compressive strength tests at three, seven, and twenty-eight days. Eight beams were also cast to study the flexural strength characteristic of waste plastic mix concrete. It was found that the reduction in workability and compressive strength, due to partially replacement of sand by waste plastic, is minimal and can be enhanced by addition of superplasticizer. 
AL-Hadithi and Al-Ani $(2015)^{2}$ investigated the change in mechanical properties of High Performance Concrete (HPC) with added waste plastics in concrete. For this purpose, $2.5 \%, 5 \%$ and $7.5 \%$ in volume of natural fine aggregate in the HPC mixes were replaced by an equal volume of Polyethylene Terephthalate (PET) waste, got by shredded PET bottles. The mechanical properties (compressive, splitting tensile, and flexural strength) evaluated at the ages of (7,28, 56 and 91) days while the static modulus of elasticity tested at (28 and 91) days. The results indicated that HPC containing PET-aggregate presented lower compressive strength and static elasticity. The splitting strength displayed an arising trend at the initial stages, however, they have a tendency to decrease after a while. On the other hand, flexural strength results gave better modulus of rapture at all ages of curing, as compared with reference concrete specimens.

In the present study, the plastic wastes were used as fibers with fixed width of $5 \mathrm{~mm}$ and three different lengths $(10 \mathrm{~mm}, 20 \mathrm{~mm}$ and $30 \mathrm{~mm})$ by ratios of $(1 \%, 2 \%$ and $3 \%)$ of cement weight. The properties of the local used plastic fibers as well as concrete components were measured and compared with Iraqi specifications. The aim of the present research is to verify the effect of using these wastes in concrete and finding the best method to use it in improving concrete properties.

\section{EXPERIMENTAL WORK}

In the experimental work, 180 cubes and 30 cylinders $(100 \times 200) \mathrm{mm}$ were casted and tested in the laboratory to find the compressive and indirect tensile strength on concrete, moreover 30 prisms of dimensions $(100 \times 100 \times 500) \mathrm{mm}$ were casted and used for finding the modulus of rupture for different waste ratios. Each type of mixing had 12 cubes of dimensions $(150 \times 150 \times 150) \mathrm{mm}$ and 6 cylinders of diameter $100 \mathrm{~mm}$ and height $200 \mathrm{~mm}$. All used materials were tested and compared with Iraqi specifications. The tested materials are:

\subsection{CEMENT}

Al-Muthanna ordinary Portland cement was used in the experimental work. Chemical and physical tests were carried out in laboratory of Engineering collage/ University of Al-Qadisiyah. Test results are shown in Table (1).

Table (1): Results of Cement Test

\begin{tabular}{|l|c|c|}
\hline \multicolumn{3}{|c|}{ Chemical Test Results } \\
\hline Oxide & Percent weight & Iraqi Specification \\
\hline $\mathrm{SiO}_{2}$ & 21.3 & - \\
\hline $\mathrm{CaO}$ & 64.64 & - \\
\hline $\mathrm{MgO}$ & 2.62 & - \\
\hline $\mathrm{Fe}_{2} \mathrm{O}_{3}$ & 2.58 & - \\
\hline $\mathrm{Al}_{2} \mathrm{O}_{3}$ & 6.16 & $\leq 4 \%$ \\
\hline Loss on ignition & 3 & $\leq 1.5 \%$ \\
\hline Irresolvable material & 1.5 & $\leq 0.8$ \\
\hline \multicolumn{3}{|c|}{ Physical Test Results } \\
\hline Property & Results & $\geq 45$ \\
\hline Soundness (Autoclave)\% & 0.02 & $\leq 600$ \\
\hline Initial setting time (min) & 85 & $\geq 15$ \\
\hline Final setting time (min) & 260 & $\geq 23$ \\
\hline \multicolumn{2}{|c|}{ Compressive strength (MPa) } \\
\hline 3 days & 16.3 & Iraqi Specification \\
\hline 7 days & 23.7 & \\
\hline
\end{tabular}




\subsection{FINE AGGREGATE}

Washed fine Aggregate was used in the mix and it was tested according to Iraqi specification No. 45. The test results showed that it within zone 2 as shown in Table (2).

Table (2): Results of Fine Aggregate Test

\begin{tabular}{|c|c|c|}
\hline Sieve size & \% of pass & Iraqi specification \\
\hline $4.75(\mathrm{~mm})$ & 100 & $90-100$ \\
\hline $2.36(\mathrm{~mm})$ & 86 & $75-100$ \\
\hline $1.18(\mathrm{~mm})$ & 68.6 & $55-90$ \\
\hline 600 micron & 37.4 & $35-59$ \\
\hline 300 micron & 8 & $8-30$ \\
\hline 150 micron & 2.4 & $0-10$ \\
\hline $\mathrm{SO}_{3}$ salt & Result & Iraqi specification \\
\hline $\mathrm{SO}_{3}(\%)$ & 0.17 & $\leq 0.5 \%$ \\
\hline
\end{tabular}

\subsection{COARSE AGGREGATE}

Shattered coarse Aggregate was used in the mix also it was tested according to Iraqi specification No. 45. The test results are shown in Table (3).

Table (3): Results of Coarse Aggregate Test

\begin{tabular}{|c|c|c|}
\hline Sieve size & \% of pass & Iraqi specification \\
\hline $37.5(\mathrm{~mm})$ & 100 & 100 \\
\hline $20(\mathrm{~mm})$ & 100 & $75-100$ \\
\hline $12.5(\mathrm{~mm})$ & 88.48 & - \\
\hline $9.5(\mathrm{~mm})$ & 33.56 & $30-6$ \\
\hline $4.75(\mathrm{~mm})$ & 0.6 & $0-10$ \\
\hline $2.36(\mathrm{~mm})$ & 0.08 & - \\
\hline $\mathrm{SO}_{3}$ salt & Result & Iraqi specification \\
\hline $\mathrm{SO}_{3}(\%)$ & 0.08 & $\leq 0.1 \%$ \\
\hline
\end{tabular}

\subsection{PLASTIC FIBERS}

Plastic fibers were manually formed from water and soft drinks bottles. These fibers were formed with a width of 5 $\mathrm{mm}$ and three different lengths $(10,20$ and 30) $\mathrm{mm}$, as shown in Figures $(1,2)$.

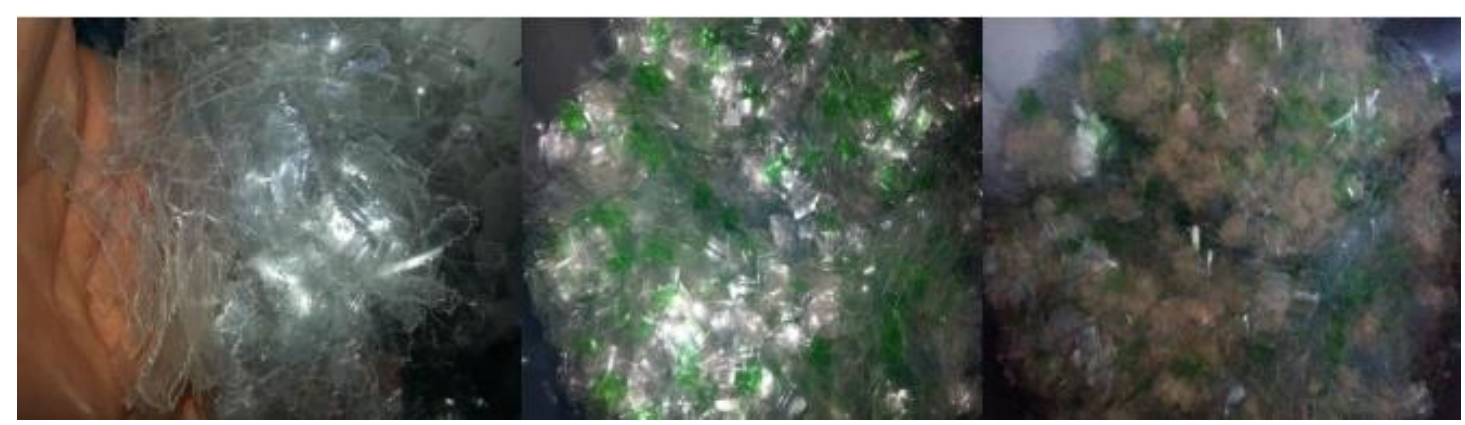

Figure (1): Formed Plastic Fibers 


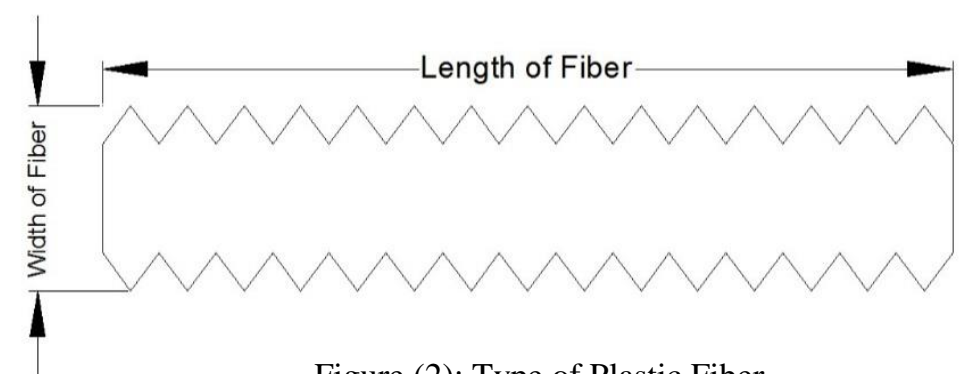

Figure (2): Type of Plastic Fiber

The density of these fibers was found equal to $1.01 \mathrm{gm} / \mathrm{cm}^{3}$ by using Archimedes theory. Also, elongation, yield stress and ultimate stress was found by testing a sample of plastic fibers using tensile test machine. The dimensions of the tested samples were as follows:

Total length of sample $=200 \mathrm{~mm}$

Effective length $=30 \mathrm{~mm}$

Effective width $=35 \mathrm{~mm}$

Thickness of sample $\approx 0.6 \mathrm{~mm}$

The results of elongation, yield stress and ultimate stress were $8 \mathrm{~mm}, 7.15 \mathrm{kN}$ and $8.25 \mathrm{kN}$ respectively.

\section{CASTING METHOD}

Mixing process was carried out by adding cement powder to fine and coarse aggregate with a mix ratio of (1:2:4) respectively. The mixture was blending in dry state for a minute to insure the homogeneity of the mixture, then the plastic fibers were added gradually during dry mixing process to avoid agglomeration of materials. Finally, the specified weight of water which is equal to $68 \%$ of cement weight was added to complete the casting process.

\section{LABORATORY TESTS}

The following laboratory tests were carried out in University of Al-Qadisiyah / College of Engineering. These tests show the effect of additive plastic fibers on mechanical properties of concrete.

\subsection{SLUMP TEST}

The base of examining workability of concrete containing plastic fibers is the slump test. Slump was measured for reference mixture which has no plastic fibers and that which contains different ratios of plastic fibers. It could be noticed that adding $1 \%$ of plastic fibers of lengths $(10 \mathrm{~mm}, 20 \mathrm{~mm}$ and $30 \mathrm{~mm})$ had no significant effect on mix workability, while the ratio of $2 \%$ shows little improvement in mix workability as shown Table (4).

Table (4): Slump Tests Results

\begin{tabular}{|c|c|c|c|c|}
\hline \multirow{2}{*}{ w/c ratio } & \multirow{2}{*}{ Fiber Length } & \multicolumn{3}{|c|}{ Slump in (mm) } \\
\cline { 3 - 5 } & & Fiber ratio (1\%) & Fiber ratio (2\%) & Fiber ratio (3\%) \\
\hline \multirow{3}{*}{0.68} & Non & 119 & 119 & 119 \\
\cline { 2 - 5 } & $10 \mathrm{~mm}$ & 120 & 120 & 118 \\
\cline { 2 - 5 } & $20 \mathrm{~mm}$ & 120 & 121 & 116 \\
\cline { 2 - 5 } & $30 \mathrm{~mm}$ & 117 & 116 & 114 \\
\hline
\end{tabular}




\subsection{DENSITY TEST}

The density of natural concrete with no fibers and those which contains fibers were measured and listed in Table (5). The results show that there is a little difference in density of concrete contains plastic fibers. This is because plastic fibers have very low density if compared with other concrete component and this difference could be neglected.

Table (5): Average Measured Density for All Tested Specimens $\left(\mathrm{kg} / \mathrm{m}^{3}\right)$

\begin{tabular}{|c|c|c|c|c|c|c|c|c|c|}
\hline \multirow{2}{*}{ Referencemix } & \multicolumn{3}{|c|}{$\begin{array}{c}\text { Density For 10mm Fiber } \\
\text { Length }\end{array}$} & \multicolumn{3}{c|}{$\begin{array}{c}\text { Density For 20mm } \\
\text { Fiber Length }\end{array}$} & \multicolumn{3}{c|}{$\begin{array}{c}\text { Density For 30mm } \\
\text { Fiber Length }\end{array}$} \\
\cline { 2 - 10 } & $1 \%$ & $2 \%$ & $3 \%$ & $1 \%$ & $2 \%$ & $3 \%$ & $1 \%$ & $2 \%$ & $3 \%$ \\
\hline 2401 & 2374 & 2357 & 2362 & 2414 & 2391 & 2429 & 2381 & 2456 & 2336 \\
\hline
\end{tabular}

\subsection{COMPRESSIVE STRENGTH TEST}

The compressive strengths of all $(150 \times 150 \times 150) \mathrm{mm}$ concrete cubes were found and recorded. The average value of compressive strength for ages (7 and 28) days was calculated and listed in Table (6). The obtained results of all specimens indicate an improvement of compressive strength in earlier age by about $40 \%$, while in 28 day age the best result was obtained was for $20 \mathrm{~mm}$ fiber length at ratio of $(2 \%)$ and was about $15 \%$. The other ratios show little improvement in compressive strength and some of those gave values less than the reference cubes as shown in Figure (3:a and 3:b).

Table (6): Average Compressive Strength for All Tested Specimens (MPa)

\begin{tabular}{|c|c|c|c|c|c|c|c|c|c|c|}
\hline \multirow{3}{*}{ Age } & $\begin{array}{c}\text { Ref. } \\
\text { Mix }\end{array}$ & \multicolumn{4}{|c|}{$\begin{array}{c}\text { Compressive Strength For } \\
10 \text { mm Fiber Length }\end{array}$} & \multicolumn{2}{c|}{$\begin{array}{c}\text { Compressive Strength For } \\
20 \text { mm Fiber Length }\end{array}$} & \multicolumn{2}{c|}{$\begin{array}{c}\text { Compressive Strength For } \\
30 \text { mm Fiber Length }\end{array}$} \\
\cline { 2 - 11 } & $0 \%$ & $1 \%$ & $2 \%$ & $3 \%$ & $1 \%$ & $2 \%$ & $3 \%$ & $1 \%$ & $2 \%$ & $3 \%$ \\
\hline 7 days & 13.98 & 15.25 & 16.49 & 15.86 & 17.9 & 19.34 & 17.9 & 16.3 & 17.37 & 15.94 \\
\hline 28 days & 20.93 & 21.5 & 22.8 & 21.29 & 21.7 & 23.07 & 20.5 & 21.1 & 21.72 & 19.1 \\
\hline
\end{tabular}

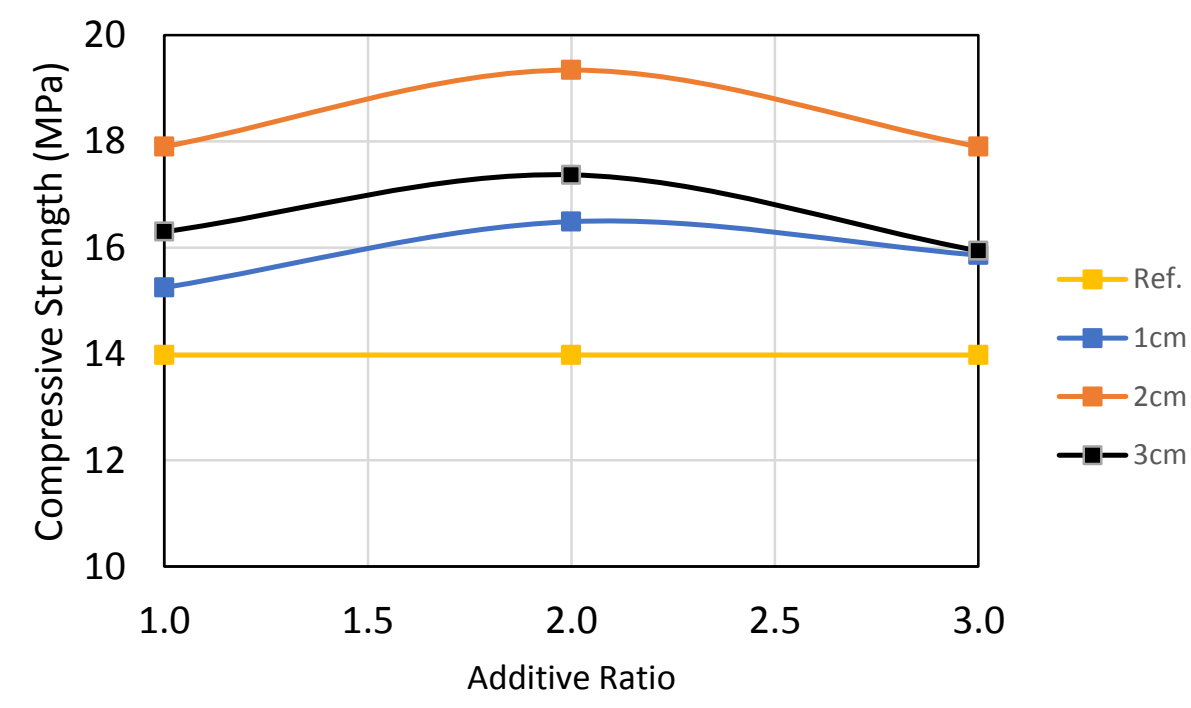

Additive Ratio (\%)

Figure 3: (a) Compressive Strength Curves for Cubes at (7) Day Age 


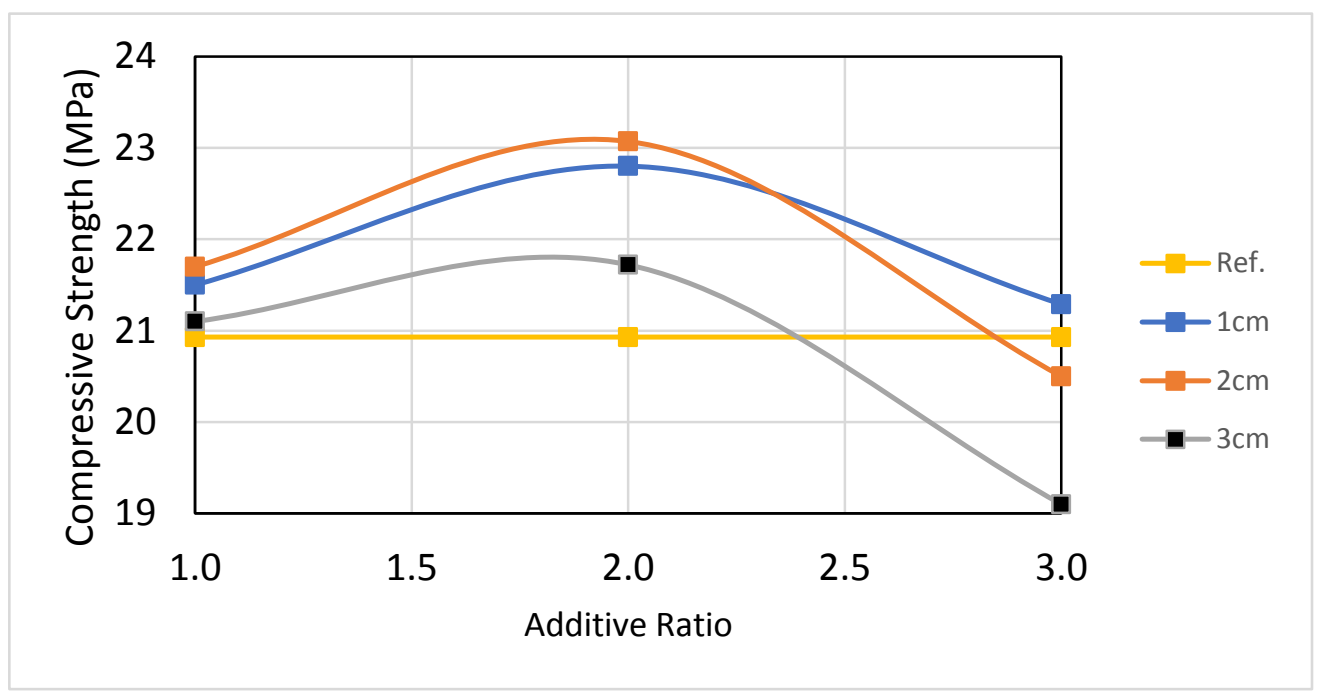

Additive Ratio (\%)

Figure 3: (b) Compressive Strength Curves for Cubes at (28) Day Age

\subsection{TENSILE STRENGTH TEST}

The indirect tensile strength of all $(100 \mathrm{~mm}$ diameter and $200 \mathrm{~mm}$ height) concrete cylinders were found and recorded. The average value of tensile strength for ages ( 7 and 28) days was also calculated and listed in Table (7). The obtained results of all specimens show an improvement of tensile strength in earlier age by about $40 \%$, while in 28 day age the best result was obtained for $20 \mathrm{~mm}$ fiber length at ratio of $(2 \%)$ which was about $35 \%$. The other ratios show less improvement in tensile strength shown in Figure (4:a and 4:b).

Table (7): Average Compressive Strength for All Tested Specimens (MPa)

\begin{tabular}{|c|c|c|c|c|c|c|c|c|c|c|}
\hline \multirow{3}{*}{ Age } & $\begin{array}{c}\text { Ref. } \\
\text { Mix }\end{array}$ & \multicolumn{3}{|c|}{$\begin{array}{c}\text { Tensile Strength For } \\
10 \text { mm Fiber Length }\end{array}$} & \multicolumn{3}{c|}{$\begin{array}{c}\text { Tensile Strength For 20 } \\
\text { mm Fiber Length }\end{array}$} & \multicolumn{3}{|c|}{$\begin{array}{c}\text { Tensile Strength For 30 } \\
\text { mm Fiber Length }\end{array}$} \\
\cline { 2 - 11 } & $0 \%$ & $1 \%$ & $2 \%$ & $3 \%$ & $1 \%$ & $2 \%$ & $3 \%$ & $1 \%$ & $2 \%$ & $3 \%$ \\
\hline 7 days & 1.57 & 2.18 & 2.19 & 2.22 & 1.99 & 2.1 & 2.1 & 1.9 & 2.08 & 2.0 \\
\hline 28 days & 2.13 & 2.5 & 2.64 & 2.53 & 2.57 & 2.89 & 2.67 & 2.43 & 2.55 & 2.46 \\
\hline
\end{tabular}

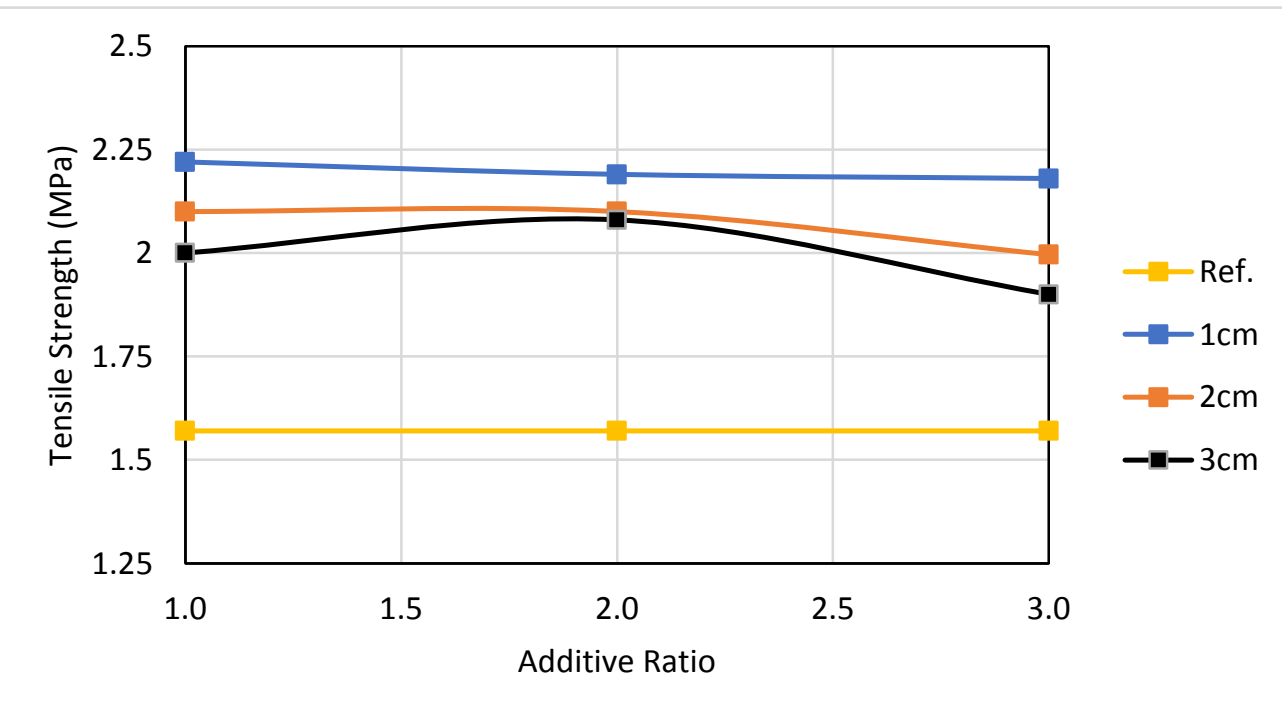

Figure 4: (a) Tensile Strength Curves for Cylinders at (7) Day Age 


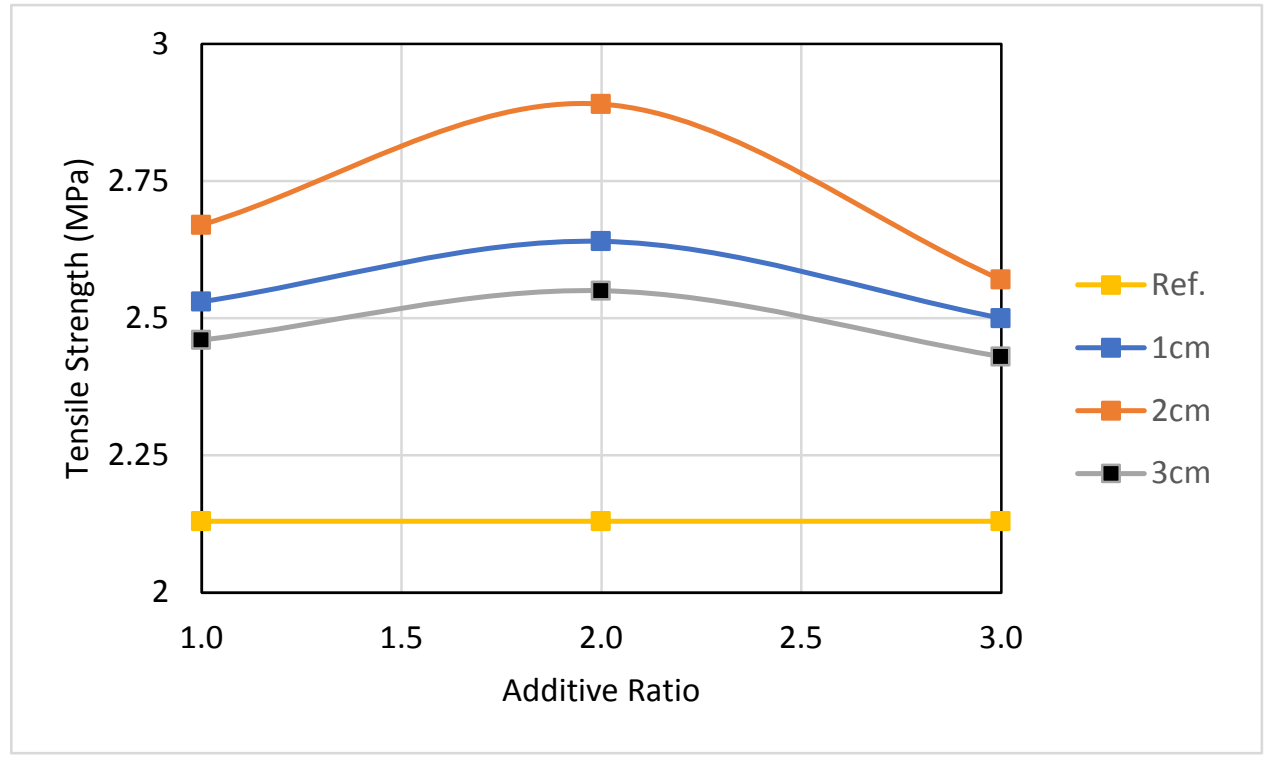

Additive Ratio (\%)

Figure 4: (b) I ensıle Strength Curves tor Cylınders at (28) Day Age

\subsection{MODULUS OF RUPTURE}

The direct tensile strength for concrete prisms of dimensions $(100 \times 100 \times 500) \mathrm{mm}$ under the action of two point loads, Figure 5, were found and recorded. The average value of tensile strength for 28 days age was calculated and shown in Figure 6 . The obtained results for all prisms show an improvement of tensile strength, spatially in additive ratio of $2 \%$ with fiber length $20 \mathrm{~mm}$ the improvement was about $7 \%$. The other ratios show less improvement in tensile strength.

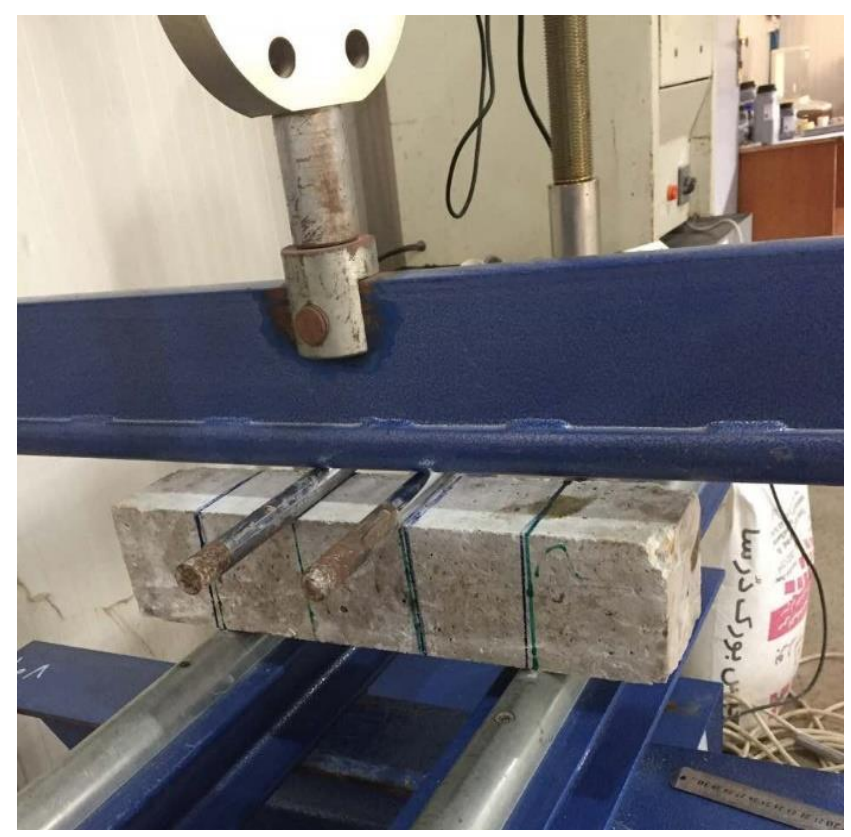

Figure 5: Modulus of Rupture Test 


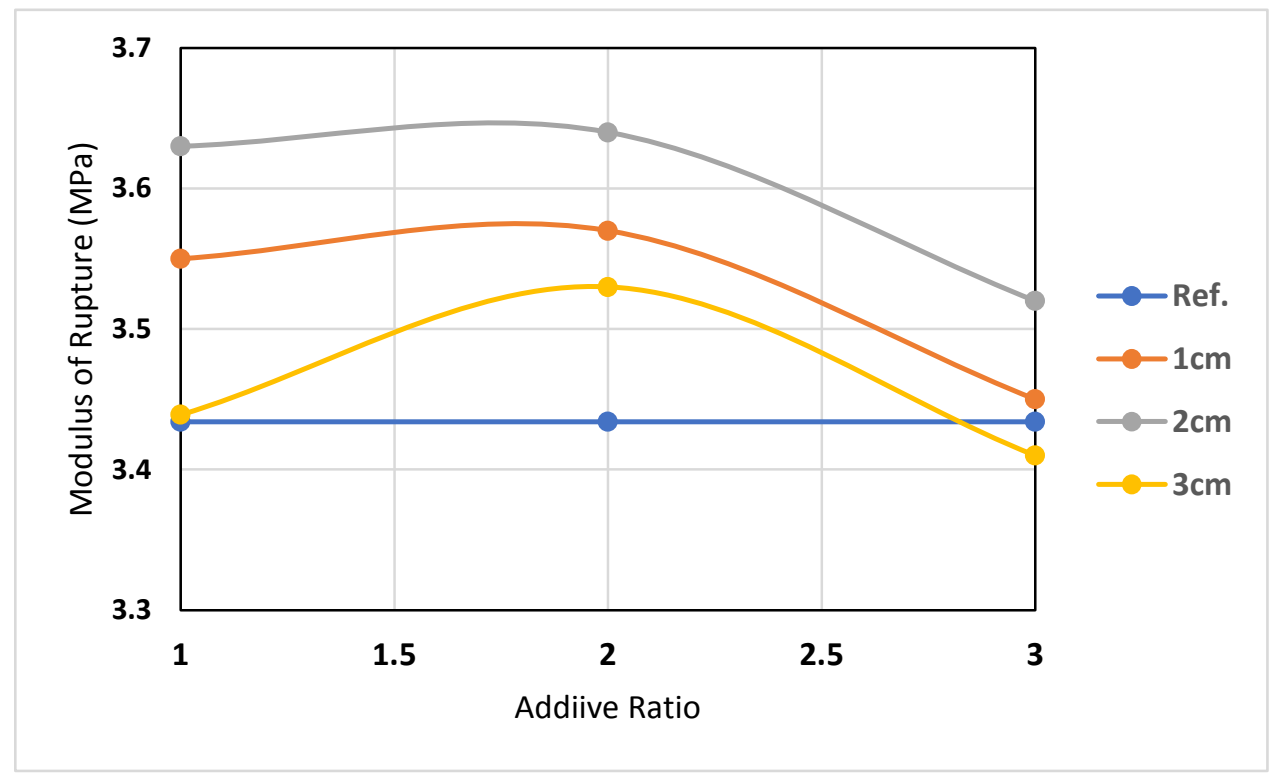

Figure 5: Modulus of Rupture results at (28) Day Age

\section{CONCLUSIONS}

After studying the previous results obtained from the laboratory tests, the following conclusions were found:

- In order to get rid of the large amount of plastic wastes, it is useful to be used in ordinary concrete structures with some improvement for its mechanical properties when these plastic fibers formed as serrated fiber.

- The addition of plastic fibers to concrete mix improve some mechanical properties of the concrete such as modulus of rupture, indirect tensile strength and compressive strength.

- The best ratio of adding plastic fibers for concrete to get maximum compressive strength and acceptable increase in tensile strength is (2\%) with length of $20 \mathrm{~mm}$ and width of $5 \mathrm{~mm}$.

- For structures with high tensile stresses, the best ratio of adding plastic fibers for concrete is (2\%) with length of 20 $\mathrm{mm}$ and width of $5 \mathrm{~mm}$.

- Also some reduction in concrete weight occurs due to additive of plastic fibers. 


\section{REFERENCES}

1- Isamil, Z.Z.. and Al-Hashimi, E.A.(2008) "Use of waste plastic in concrete mixture as aggregate replacement", J. of Waste Management, Vol.28, issue 11,pp.2041-2048.

2- AL-Hidithi, A.I., and AL-Ani, M.(2015) F." Mechanical Properties of High Performance Concrete Containing Waste Plastic as Aggregate” J. of Engineering,Vol.21,No.8.

3- American Society for Testing and Materials ASTM C293-10, 2010, Standard Test Method for Flexural Strength of Concrete (Using Simple Beam With Center-Point Loading), American Society for Testing and Materials, pp.(1-3) .

4- American Society for Testing and Materials C496-04, 2004, Standard Test Method for Splitting Tensile of Cylindrical Concrete Specimens, American Society for Testing and Materials, pp. (1-5).

5- Biel, T., D., and Lee, H., (1994). "Use of recycle tire rubbers in concrete." Proc., ASCE 3rd Mat., Eng. Conf., Infrastructure: New Mat. And Methods of Repair, pp.351 - 358.

6- B.S.1881, Part 116,1989, Method for Determination of Compressive Strength of Concrete Cubes, British Standards Institution .

7- Eldin, N. N., and Senouci, A. B. (1993), "Rubber-tire particles as Concrete aggregate.” J. Mat. In Civ. Eng., ASCE, 5(4), pp. 478 - 496.

8- Sharma, R.and Bansal, P. "Use of different forms of waste plastic in concrete", J. of cleaner Production, Vol.112,part 1, 2016, pp.473-482.

9- Iraqi Specification, No.45, 1984, Aggregate from Natural Sources for Concrete and Construction.

10- Iraqi Specification, No.5,1984, Portland Cement.

11- Konin, A., (2011), "Effect of plastic waste content on Physico-Mechanical properties of flexible pavements", international journal of civil and structural engineering, Vol.2, No.1, pp382-394.

12- Rai,B., Rushad, S.T., Bhavesh Kr, and Dugga, S.K. "Study of Waste Plastic Mix Concrete with Plasticizer" ISRN Civil Engineering, Vol.2012, Article ID 469272, 5pages.

13- Saikia , N. , and de Brito, J. , 2014, "Mechanical properties and abrasion behaviour of concrete containing shredded PET bottle waste as a partial substitution of natural aggregate", Construction and Building Materials, Vol.52, pp. 236-244 .

14- Schimizze, R., Nelson, J., Amirkhanian, S., and Murden, J. (1994). "Use of waste rubber in light - duty concrete pavements." Proc., ASCE, 3RD Mat. Eng. Conf., Infrastructure: New Mat. And Methods of Repair, pp.367 - 374.

15- Soroushian, P., Mirza,F., and Alhozaimy, A., (1995). "Permeability characteristics of poly-propylene fiber reinforced concrete.” ACI Materials Journal, Vol.92, No.3, pp.291-295.

16- Yin,W.,Hsu,T.C.,(1995) "Fatigue behavior of steel fiber reinforced concrete in uniaxial and biaxial compression" ACI Materials Journal Vol.92, No. 1, pp.71-81. 